\title{
7q11.23-q21.2 Microdeletion is associated with moderate structural brain abnormalities and global developmental delay: first report
}

\author{
George T Vasileiadis, ${ }^{1}$ Jennifer Carter, $^{2}$ Richard H Scott ${ }^{2}$
}

${ }^{1}$ Department of Neonatology, BHR University Hospitals NHS Trust, London, UK

${ }^{2}$ Department of Clinical Genetics, North East Thames Genetic Service, London, UK

\section{Correspondence to} Dr George T Vasileiadis, George.Vasileiadis@ bhrhospitals.nhs.uk

Accepted 9 September 2015

\section{DESCRIPTION}

We present a case of a male infant born at $29^{+6}$ weeks (weight $1670 \mathrm{~g}$ ) following an antepartum haemorrhage. Antenatal scans did not reveal any abnormality; the infant had a high arch palate and

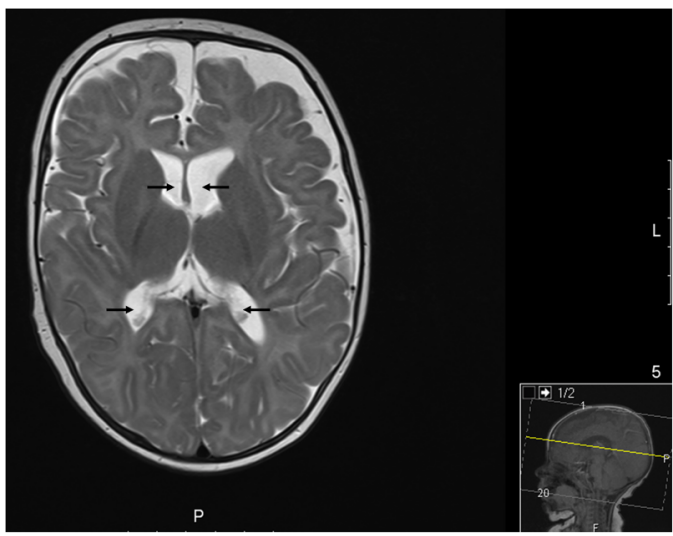

Figure 1 Enlarged frontal and occipital horns of both lateral ventricles (arrows). small germinal matrix bleed but no intraventricular haemorrhage. He was noticed to be moderately hypotonic at the age of term equivalent. Brain MRI revealed moderate ventriculomegaly bilaterally with no hydrocephalus (figure 1), and moderate hypoplasia of the corpus callosum (figure 2). ${ }^{1}$ Interestingly, detailed developmental assessment (Bayley III) at the adjusted for prematurity age of 13.5 months showed a global developmental delay affecting cognitive, communication and motor domains (percentile ranks: $1,4,0.1$, respectively). ${ }^{2}$ His weight plotted on the 91st centile and his head circumference on the 50th.

Genetic studies: microarray detected a heterozygous $16.7 \mathrm{Mb}$ microdeletion at chromosome 7q11.23-q21.2. Fluorescence in situ hybridisation analysis using probe RP11-185D15 confirmed the analysis. The deletion was not present in either parent, encompassed 76 known genes and did not overlap the Williams-Beuren critical region. This is the first report of such deletion and further cases with closely overlapping microdeletions are required to clarify which of the genes in the deleted interval contribute to the child's phenotype and long-term outcome.
To cite: Vasileiadis GT Carter J, Scott RH. BMJ Case Rep Published online: [please include Day Month Year] doi:10.1136/bcr-2015212175

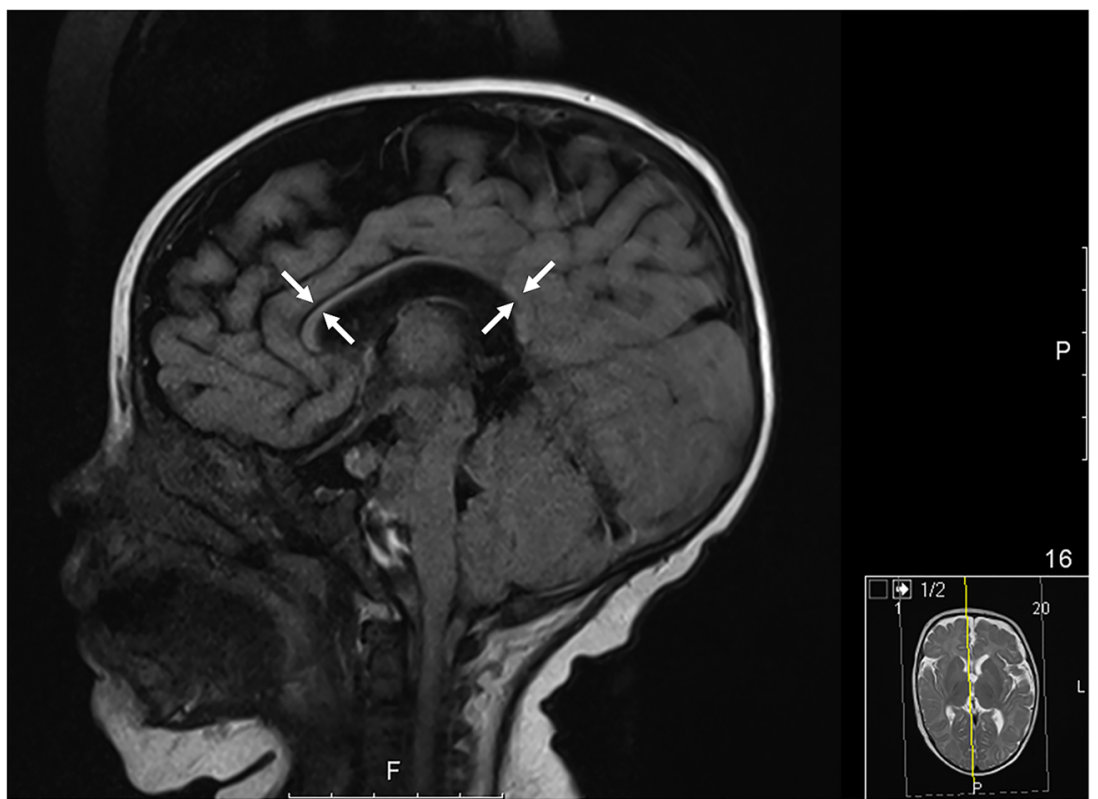

Figure 2 Hypoplastic corpus callosum (between arrows). 


\section{Learning points}

- Differential or overlapping diagnoses: Prematurity is associated with ventriculomegaly, and both may be associated with hypotonia and developmental delay. However, genetic abnormalities can also be associated with hypotonia and developmental delay.

- Callosal abnormalities are present in a significant proportion of infants with ventriculomegaly, irrespective of prematurity.

- Combined callosal abnormality/ventriculomegaly and global developmental delay may be associated with 7q11.23-q21.2 microdeletion.
Competing interests None declared.

\section{Patient consent Obtained.}

Provenance and peer review Not commissioned; externally peer reviewed.

\section{REFERENCES}

1 Li Y, Estroff JA, Khwaja O, et al. Callosal dysgenesis in fetuses with ventriculomegaly: levels of agreement between imaging modalities and postnatal outcome. Ultrasound Obstet Gynecol 2012;40:522-9.

2 Bayley N. Bayley scales of infant development. 3rd edn. San Antonio, TX: The Psychological Corporation, 2006.

Copyright 2015 BMJ Publishing Group. All rights reserved. For permission to reuse any of this content visit http://group.bmj.com/group/rights-licensing/permissions.

BMJ Case Report Fellows may re-use this article for personal use and teaching without any further permission.

Become a Fellow of BMJ Case Reports today and you can:

- Submit as many cases as you like

- Enjoy fast sympathetic peer review and rapid publication of accepted articles

- Access all the published articles

- Re-use any of the published material for personal use and teaching without further permission

For information on Institutional Fellowships contact consortiasales@bmjgroup.com

Visit casereports.bmj.com for more articles like this and to become a Fellow 